\title{
A Quest for Defining Terrorism in International Law: The Emerging Consensus
}

\author{
Mohammed Salman Mahmood \\ Ahmad Masum \\ School of Law \\ UUM College of Law, Government and International Studies
}

\begin{abstract}
The United Nations (UN) has no internationally-agreed definition of terrorism. The definitional impasse has prevented the adoption of a Comprehensive Convention on International Terrorism. Even in the immediate aftermath of 9/11 the UN failed to adopt the Convention, and the deadlock continues to this day. The prime reason is the standoff with the Organization of the Islamic Conference (OIC). The Arab Terrorism Convention and the Terrorism Convention of the Organization of the Islamic Conference defines terrorism to exclude armed struggle for liberation and self-determination. This increased its complexity and vagueness. The aim of this paper is to examine the definitional aspect of terrorism and the challenges faced in adopting a single universally accepted definition by the international community. The methodology adopted in this paper is purely a library based research focusing mainly on primary and secondary sources. The paper concludes that nations or states have to come to agreement on a definition of the term "terrorism", for without a consensus of what constitute terrorism, nations or states could not unite against it. A general definition of terrorism is necessary in order for the international community to fight against terrorism in a precise way.
\end{abstract}

Keywords: International law, international terrorism, terrorism, liberation, selfdetermination.

\section{Introduction}

The term "terrorism" comes from Latin terrere "to cause to tremble". The term became popularized during the "Reign of Terror" and carried out by the revolutionary government in France from 1793 to 1794 (Juergensmeyer, 2003, p. 5). In a modern context, it is used widely to refer, mainly to either terrorism or international terrorism (Foerster, Heinz, Patricia, \& Lawrence, 1960; Schmid, 2011 \& 2012). We have to bear in mind that with increasing number of violence and attacks in many countries, the effects of terrorism are far profound i.e. targeting not only the country where terrorist acts take place but also other neighbouring and even distant countries. This is similar to cancer as a disease. Cancer does not only affect a particular part of the patient's body, but it spreads to other intact areas as well. 
Due to the effects of terrorism at all levels in the form of crimes that threaten people's lives, civil freedom, institutions and the community, nationally and internationally, several definitions, including oppressions of people, violence and cruelty, have been presented to refer to terrorism (Carlton \& Schaerf, 1975). It should be noted from the outset that although terrorism is considered as a crime and despite many conferences were held, focusing mainly on conventions and national legislations, the 70 years of attempts to reach an international comprehensive agreement to define terrorism were fruitless (Ben, 2006; Hassan, 2011). However, recently, due to the advancement of its means and ways historically, terrorism has got a new identity. Among all previous movements, Al-Qaeda looked a distinguished one due to their extremism when targeting their objectives and operations, which are far-flung, co-ordinated and ruthless. According to Adam (2005), international terrorism is believed to be more threatening and deadly than any other conventional fights, conflicts or wars. This was obviously evidenced in the huge damages and the violation of 5,000 people's rights and lives caused by Al-Qaeda's 9/11 attacks. Consequently, several bouts of international campaigns were initiated following the terrorist attacks of 9/11 (September 11) in both New York and Washington in 2001. These developments have triggered scholarly interest in terrorism particularly on the subject of international terrorism.

No comprehensive definition of the term "terrorism" has been given or agreed upon by the States regardless of the continuous historical controversy over it as a debated issue implying offence and aggression, particularly the period preceding and following the terrorist attacks of 9/11 (September 11). The failure by the international community is not only in providing a definition, but also in addressing methodologically and scientifically the seriousness and effect of terrorism (Hoffman, 1998). Due to the lack of an International Convention at the UN providing an established and comprehensive definition of terrorism, it has become difficult or if not near impossible to fight terrorism both domestically and internationally. Different countries at the international level have different views on the meaning of terrorism. But it must be pointed out that despite the historic controversy over the definition of terrorism, international consensus has gradually emerged condemning terrorist acts as a violation of the "laws of nations" (Hickman, 2011).

This paper aims to examine the definitional aspect of the term "terrorism" and the challenges faced in adopting a single universally accepted definition by the international community. The paper is divided into five sections. The first section presents attempts by the international community to define terrorism generically since 1920s. These attempts have all been unsuccessful since the international community could not agree on the exact meaning of terrorism. The second section focuses on the challenges faced by the international community in adopting a single universally accepted definition of terrorism. The third section deals with international legal instruments adopted by the international community to prevent terror acts. The fourth section addresses the emerging consensus on certain elements of definition of terrorism by the international community. The fifth section shall focus on the conclusion, which will embrace some recommendations in order 
to overcome the problems we face in the fight against terrorism as a result of the absence of a universally accepted definition. In this paper, the authors argue that although there is no universally accepted definition of terrorism in international law, it is still arguable that there is a core definition of terrorism at international law that provides guidance to States enacting terrorism legislation. However, that to have an effect, States must look to international law and accept its guidance. All States should treat the international law definitional jurisprudence as setting a minimum level, not a maximum.

\section{Attempts to Define Terrorism by the International Community}

Terrorism has been on the international agenda since 1934, when the League of Nations took the first major step towards outlawing the scourge by discussing a draft convention for the prevention and punishment of terrorism (United Nations Action to Counter Terrorism, http://www.un.org/en/terrorism/instruments.shtml). Although the Convention was eventually adopted in 1937, it never came into force due to the failure of the ratification process (Fidanci, 2006). Under this section, we intend to address the attempts made by the international community to arrive at a generic definition of terrorism by way of making reference to the following historic events:

\section{$1 \quad 1937$ League of Nations Convention}

It is without doubt that the most significant early modern attempt to define terrorism as an international crime was undertaken by the League of Nations between 1934 and 1937 (Marston, 2002). The Convention was drafted in a number of phases between 1935 and 1937 (Geneva: $1^{\text {st }}$ Session 8 May 1935; $2^{\text {nd }}$ Session 10 Feb 1936; and $3^{\text {rd }}$ Session $26^{\text {th }}$ April 1937). An international diplomatic conference met in November 1937 to draft and adopt a convention based on the final draft submitted by Committee for the International Repression of Terrorism (CIRT). The Final Act of the diplomatic conference adopted two international conventions-the first defining international terrorist offences, and the second creating an international criminal court to punish the offences in the first treaty (Saul, 2005).

In addition to the above, the first treaty, the 1937 Convention for the Prevention and Punishment of Terrorism, required States to criminalize terrorist offences and encouraged States to exclude the offences from the political offence exception to extradition (Saul, 2005). It attracted 24 signatories: 12 were European States, seven were Caribbean, Central or South American States, and five others included major States from other regions. The Convention was only ratified by one (colonial) State- India, which had separate League membership to Britain- and never entered into force (Saul, 2005). The Second World War diverted attention from the Convention and with the demise of the League of Nations, interest in the Convention never revived. It should be categorically pointed out that despite never entering into force, the 1937 League Convention indicates the early views of States on terrorism. For example, Article 1(1) reaffirms as a 'principle of international law' that it is 'the duty of every State to refrain from any act designed to encourage terrorist activities 
directed against another State and to prevent acts in which such activities take shape'. States were, however, careful to exclude armed forces from the scope of the Convention, including acts committed in civil wars (Geneva: $3^{\text {rd }}$ Session Report, 26 ${ }^{\text {th }}$ April 1937). Article 1(2) of the Convention defines 'acts of terrorism' as 'criminal acts directed against a State and intended or calculated to create a state of terror in the minds of particular persons, or group of persons or the general public. As mentioned earlier, it is important to note that the definition given here does not exist and the Convention is not part of international law today because it was never entered into force due to the failure of the ratification process (Fidanci, 2006).

The International Law Commission considered terrorism when drafting its 1954 Draft Code of Offences against Peace and Security of Mankind (Part I) (Saul, 2005). Although the 1954 ILC Draft Code was never formally adopted by the General Assembly or in treaty form, it provides an insight into mid- $20^{\text {th }}$ century thinking about terrorism in international law (Saul, 2005). Terrorism was explicitly linked to the concept of aggression. Article 2(6) defines an offence 'against the peace and security of mankind' of the undertaking or encouragement by the authorities of a State of terrorist activities in another State, or the toleration by the authorities of a State of organized activities calculated to carry out terrorist acts in another State. It would suffice to note that the offence only covers conduct by those acting for the State, and not the activities of non-State actors. Furthermore, due to insurmountable disagreement about the definition of aggression, the General Assembly postponed further consideration of the 1954 ILC Draft Code until a Special Committee on defining aggression had reported (UNGA res 897 (IX) 1954). As a matter of fact subsequent attempts to define aggression have eschewed any reference to terrorism and severed the early linkage between these concepts. A (non-exhaustive) General Assembly resolution defining 'aggression' in 1974 makes no reference to terrorism, nor does the definition in the 1996 ILC Draft Code or in the 1998 Draft Rome Statute. Hence, it is arguable that although the term 'terrorism' might seem self-evident, in practice it is hard to agree upon a legal definition at the international level. This dilemma can be seen for example in the definition of 'aggression' as stated above. Take for instance the discussion in Rome during the drafting of the International Criminal Court Statute. The Statute did not include 'aggression' as one of its 'grave crimes' because the conference could not agree upon its definition, even though efforts to define the crime of aggression have been underway since 1948 and despite the fact that Article 51 of the UN Charter had shed the light on this issue.

\section{1 and 1996 ILC Draft Code of Crimes}

It should be noted that after the postponement of 1954, the ILC resumed consideration of the Draft Code in 1982. Following nine reports by a Special Rapporteur between 1983 and 1991, the ILC adopted the first reading of a Draft Code in 1991 (Saul, 2005). Article 24 of the 1991 ILC Draft Code, based on Article 2(6) of the 1954 Draft Code, proposed an offence where a State agent or representative commits or orders the following: 
Undertaking, organizing, assisting, financing, encouraging or tolerating acts against another State directed at persons or property and of such a nature as to create a state of terror in the minds of public figures, groups or persons or the general public.

Based on the above draft provision, it partially incorporates the 1937 League of Nations Convention definition; added the notions of 'organizing', 'assisting' and 'financing'; and included an express reference to acts against property. Despite this being the case, some ILC members objected that the definition was tautological and that it would be better to refer to 'a state of fear' rather than a 'state of terror' (Saul, 2005). The difficulty of proving subjective fear was also raised. Furthermore, the proposed offence did not apply to private individuals and requires a State connection (Sunga, 1997). This again created some grounds for disagreement. For example, it is possible that groups of individuals could threaten peace and security. In other words, terrorism should cover both private as well as State conduct.

In addition to the above, the final ILC Draft Code (Part II) was adopted in 1996 (ILC, Report on 48 ${ }^{\text {th }}$ Session 6 May-26 July 1996). While earlier drafts between 1990 and 1995 had included distinct Articles on 'international terrorism', a discrete terrorist offence was subsumed by, and recast within, the final Article 20 on 'war crimes'. The war crime of 'acts of terrorism' in Article 20 embodied the simple prohibition in Article 4(2)(d) of the Protocol II (ILC, Report on $48^{\text {th }}$ Session). The position was made clear regardless of the suggestion to substitute the phrase 'state of terror' to 'state of fear' on the basis that there was no longer any broader offence of creating a state of terror outside of armed conflict.

It is important to note that while the 1996 ILC Draft Code was not adopted as a treaty, the General Assembly drew it to the attention of the Preparatory Committee on the Establishment of an International Criminal Court (UNGA res 51/160 1996). Hence, it is important to make reference to Article 5 of the 1998 Draft Rome Statute, which was presented to the 1998 Rome Diplomatic Conference. By virtue of the Article, 'crimes of terrorism' comprised of three distinct offences. The first offence was that of: undertaking, organizing, sponsoring, facilitating, financing, encouraging or tolerating acts of violence against another State directed at persons or property and of such a nature as to create terror, fear or insecurity in the minds of public figures, groups of persons, the general public or populations, for whatever considerations and purposes of a political, philosophical, ideological, racial, ethnic, religious or such other nature that may be invoked to justify them. Looking at the first offence, clearly it resembles the 1991 ILC Draft Code and not limited to armed conflict (as in the 1996 ILC Draft Code). The first offence also shares elements of the 1937 League of Nations Convention definition and a 1994 General Assembly working definition.

Regarding the second offence, it comprised any offence in six sectoral treaties such as: the 1971 Montreal Convention; 1970 Hague Convention; 1973 Protected Persons Convention; 
1979 Hostages Convention; 1988 Rome Convention and 1988 Rome Protocol (Saul, 2005). On the other hand, the third offence involved 'the use of firearms, weapons, explosives and dangerous substances when used as a means to perpetrate indiscriminate violence involving death or serious bodily injury to persons or groups or persons or populations or serious damage to property'.

With all the energy and time vested, terrorism was not included in the 1998 Rome Statute as adopted. It is unfortunate that despite widespread international condemnation of terrorism, no generally acceptable definition could be agreed upon. It is inevitable to point out that terrorism was not included for a variety of reasons such as: its legal novelty and lack of prior definition; disagreement about national liberation violence and so forth. At this point, it is important to emphasize that making a single universal definition of terrorism under international law is extremely difficult since there is always a possibility for the actions of a person or group are described as terrorism (criminal acts) by one side, while the same actions are called as the movement for freedom (political acts) by the other side (Fidanci, 2006).

\section{Draft Nuclear Terrorism Convention}

Between 1997 and 2000 an Ad Hoc Committee established by the General Assembly in 1996 successfully drafted the 1997 Terrorist Bombings Convention and the 1999 Terrorist Financing Convention (Saul, 2005). The General Assembly also tasked the Committee with drafting a treaty to suppress nuclear terrorism, based on a draft text submitted by Russia in 1997, as subsequently revised. The draft text was influenced by the 1980 Vienna Convention and the 1997 Terrorist Bombings Convention (Ad Hoc Committee Report, 1998). Despite annual discussions, by the end of 2004, agreement had still not been reached on the draft and little progress was made after 1998.

Perhaps it has to be pointed out that the draft preamble expresses the convention's rationale, stating that 'acts of nuclear terrorism may result in the gravest consequences and may pose a threat to international peace and security' and that 'existing multilateral legal provisions do not adequately address those attacks'. It would suffice to note that the convention aims to fill lacunae left by 1980 Vienna Convention, by covering a wider range of 'targets, forms and acts of nuclear terrorism' (Corell, 2002). In contrast, the 1980 Vienna Convention is limited to offences relating to nuclear material while in international transport or in domestic use, storage and transport (1980 Vienna Convention, art 7).

Furthermore, draft Article 2(1) establishes objective offences where a person unlawfully and intentionally possesses or uses radioactive material or devices with the intent to cause death or serious bodily injury, or to cause substantial damage to property or the environment. It creates the further offences of using radioactive material or devises, or using or damaging a nuclear facility, with the intent to compel a natural or legal person, an international organization or a State to do or refrain from doing an act. States must legislate to punish 
these acts, 'in particular where they are intended or calculated to provoke a state of terror in the general public or in a group of persons or particular persons'. It is vital to note that while deriving from a 1994 General Assembly definition, itself similar to the 1937 League of Nations Convention definition, the notion of a 'state of terror' is not an element of the offences, nor are the offences described as 'nuclear terrorism' as such (Saul, 2005 \& 2006).

By 2003, the principle unresolved issue was the treaty's scope of application. Draft Article 4 proposes to exclude the 'activities of armed forces during armed conflict' which are 'governed' by International Humanitarian Law (IHL). It further excludes the 'activities' of State military forces 'in the exercise of their official duties, inasmuch as they are governed by other rules of international law'. Although an identical provision was adopted in the 1997 Terrorist Bombings Convention, some States wanted the Draft Nuclear Terrorism Convention to apply to the activities of State armed forces, and/or State-sponsored nuclear terrorism (Saul, 2005). This position is understandable given that States are the primary possessors of nuclear material. Some felt that the 1997 provision was ambiguous, while others believed it should take into account the contested legality of the use of nuclear weapons in armed conflict.

The authors would like to reiterate that the difficulty in reaching agreement on the convention reflects the highly politicized nature of the legality of the use and possession of nuclear weapons by States. Hence, the mandate of the Ad Hoc Committee drafting the convention was renewed in 2004 (UNGA res 54/110, 1999). It would thus suffice to note that agreement on the convention may depend on States first reaching agreement on the definition of terrorism in the Draft Comprehensive Convention, or even on the resolution of conflicts in the Middle East and over Kashmir (Rostow, 2002).

\section{6}

\section{Draft Comprehensive Convention}

The draft preamble of this Convention condemns 'all acts, methods and practices of terrorism as criminal and unjustifiable, wherever and whomever committed' (Ad Hoc Committee Report 2002). Draft Article 2(1) proposes an offence if a person 'unlawfully and intentionally' causes: 'death or serious bodily injury to any person'; 'serious damage to public or private property'; or 'damage to property, places, facilities, or systems... resulting or likely to result in major economic loss'. The purpose of any such conduct, 'by its nature or context', must be 'to intimidate a population, or to compel a Government or an international organization to do or abstain from doing any act' [Draft Comprehensive Convention, art 2(2), (3) and (4) (a)-(c)]. In other words, the prohibited acts must be motivated by purposes of intimidation or compulsion, but there is no requirement that acts be motivated by political aims or objectives. The treaty proposes to exclude the offences from the political offence exception to extradition (Draft Comprehensive Convention, art 14).

Based on the above, it appears that unlike the 1997 Terrorist Bombings Convention, the Draft Comprehensive Convention proposes to protect private property as well as public 
property. It captures a wider range of acts against property than the EU Framework Decision, by referring to 'serious damage' rather than 'extensive destruction' (Dumitriu, 2005; Saul, 2005). Furthermore, like the 1997 Terrorist Bombings Convention, the Draft Comprehensive Convention protects only States or international organizations from compulsion, and not NGOs, political parties, corporations or other social groups (Saul, 2005).

The Draft Comprehensive Convention was also met with some resistance. The first resistance being the application of the Convention i.e. whether it should exclude the activities of the 'parties' - rather than the 'armed forces' during an armed conflict, since reference only to 'armed forces' might exclude other participants in armed conflict under IHL (OIC proposal, in Ad Hoc Committee Report, 2002), particularly as 'parties' are mentioned in the Hague Regulations and the Geneva Conventions. It is important to note that the 1997 Terrorist Bombings Convention excludes the 'activities of armed forces during an armed conflict' from that Convention, as well as the activities of State military forces exercising their official duties 'inasmuch as they are governed by other rules of international law'. This approach is also followed in the EU Framework Decision (Dumitriu, 2005). It should be noted that proposed Article 18 of the Draft Comprehensive Convention is based on 1997 Terrorist Bombings Convention. However, the 1997 Terrorist Bombings Convention refers to armed forces 'as understood' under IHL, but definition in the Draft Comprehensive Convention itself would provide further clarity, particularly concerning application to nonState forces in non-international armed conflicts under Protocol II. Clearly, reference to the 'parties' would be too broad, since it would exclude all State activity in armed conflict - not just military activities - as well as numerous non-State armed groups (Ad Hoc Committee Report, 2004).

Apart from the disagreement above, a second disagreement was based on whether situations of 'foreign occupation' should also be excluded from the Draft Comprehensive Convention, in addition to 'armed conflict'. This proposal was put forward by OIC proposal to exclude activities of the 'parties' and was intended to cover situations where there are no hostilities and IHL may not strictly apply. Politically, it was aimed at excluding non-State violence against Israel in the Palestinian Occupied Territories and against India in Kashmir (Rostow, 2002). It has been argued that this OIC proposal would 'eviscerate' the Convention, by reintroducing a national liberation exception (Halberstam, 2003). Other States wanted even more explicit exemptions for self-determination movements. The third disagreement was whether State military forces exercising their official duties should be excluded from the Convention if they were merely 'governed' by international law or required to be 'in conformity' with it. The OIC proposed that military forces would be liable for terrorism if they were not 'in conformity' with international law, including genocide, torture, IHL, or State responsibility. These States felt that the Convention should cover State and Statesponsored terrorism, notwithstanding the application of existing international law to State conduct. It seems that the OIC proposal lacks balance since the activities of non-State forces are not similarly classified as terrorism if they are not in conformity with international law (Saul, 2005; 2006). 


\section{Challenges Faced by the International Community to Adopt an Accepted Universal Definition of Terrorism}

Schmid and Jongman (1988), in their book Political Terrorism, list 109 different definitions of terrorism in existence between 1936 and 1981 (Ganor 2002, p. 290). Moreover, as Golder and Williams (2004, p. 270) say, the number would be more, but all efforts to create generally recognized legal definition of terrorism have failed in international law. There are many reasons for not reaching a consensus on the definition of terrorism in international community and cultural relativism is seen as the main reason for the disagreement. It appears that because of this cultural relativism argument, the definition of terrorism shows differences even from community to community. Likewise, it has been defined differently by politicians, security experts and journalists (Ganor 2002, p. 290). As Begorre-Bret (2005, p. 1993) remarks: 'Failure is in their interest because it strengthens ethical and juridical relativism'. Based on this assertion, it can be said that cultural relativism is acknowledged as a challenge. Moreover, as Ganor (2002, p. 290) claims, in the absence of an objective and authoritative description, which is acknowledged by all nations, fighting against terrorism will suffer from cultural relativism. The problem arises from the fact that we are seeking a firm definition of untenable terms. As Ganor $(2002$, p. 287) claims, there is a tendency to believe that an objective and universally recognized definition of terrorism can never be achieved because this term is a variable. For instance, one man's terrorist is another man's freedom fighter and he adds that the answer will alter according to subjective view of the describer.

The concept of terrorism itself has been seen as another form of challenge hindering the process of having an accepted universal definition. According to some scholars, the inability to define terrorism in international law can be acceptable because as Schmid (2004a, p. 395) points out 'terrorism is a 'contested concept' and political, legal, social science and popular notions of it are often diverging'. Hence, terrorism appears not to be a mere legal issue; it is in the scope of politics and law (Schmid, 2004b). Perhaps some would argue that law alone is inadequate to designate the concept of terrorism. It may well be that the problem is the political side of terrorism, and possibly for this reason, the definition of terrorism differed throughout history. As Begorre-Bret (2005, p. 1988) notes, over the years: 'the member States did not manage to reach any consensus concerning the definition of terrorism' because every State has different backgrounds and regimes. However, if one State defines terrorism broadly and the other has a narrow one, a constant consensual policy will be a difficult goal. Concordantly, Begorre-Bret (2005, p. 1992) points out the subjective concept of terrorism; that it is not feasible to define terrorism since it is impossible to discern objectively between legitimate force and illegitimate violence, between " the hero" and "the barbarian", and between "the warrior" and "the murderer". There is no objective explanation of terrorism but only several partial and ideological characterizations of the violence of the foe.

It could also not be denied that the other challenge facing the international community in adopting a universally accepted definition of terrorism is based on the interest of the States. 
Indeed it is unfortunate that when States define terrorism they focus on their own priorities in reference to their national interest; therefore, the definition should be disinterested. As Ganor (2002, p. 290) remarks: 'if all the enlightened countries do not change their priorities, and do not disenable their political and economic interest, it will not be feasible to wage an effective war against terrorism'. In this regard, Begorre-Bret (2005, p. 1995) makes an important point, that the States and criminal organizations themselves create the disputes and confusion about definition because they do not wish to limit their reasons to the use of force. Perhaps it is the policy of certain Nations or States to avoid clear-cut definitions, thereby giving them ample discretion in their actions or interests.

The final challenge facing the international community in adopting a universally accepted definition of terrorism is based on its own reluctance to define terrorism. How far is that actually true? This assertion of the international community being reluctant to define terrorism is purely based on a lame excuse i.e. although international organizations are aware of the definition issue, they hesitate to create universally accepted definition. They condemn terrorism but they do not define, so what do they reflect on? As Walter, Vonkey, Roben, and Schorkopf (2004; cited in Golder and Williams 2004, p. 271) accept, it is clearly required to create a consistent legal definition of terrorism. It should be borne in mind that even international definition or treaties alone cannot solve the problem since the States cooperations are essential in order to eliminate the threat of terrorism and make the world a safer place.

\section{The Emerging Consensus on Certain Elements of Definition of Terrorism}

Regardless of the previous discussions on the issue of lack of a single accepted universal definition of terrorism by the international community, it would suffice to note that this has resulted in the international law choosing various forms of counter-measures against certain acts of terrorism under different international conventions since 1963 and to introduce measures to make sure international co-operation to investigate, combat and eliminate terrorist incidents in certain situations (Cassese, 2003). Therefore, the major anti-terrorism conventions are drafted within the framework of the UN and ratified by many States. Accordingly, at present, there are 14 international conventions addressing terrorism and related activities, each covering a specific type of criminal activities, including seizure of airplanes, political assassination, the use of explosives, hostage-taking, nuclear terrorism and assorted bombings. It is vital to note that all these conventions require contracting States to introduce appropriate national legislations in their own jurisdiction in order to punish the specific crimes mentioned by each convention (Fidanci, 2006). Furthermore, by way of resolution 1373 of 28 September 2001, it was decided by the UN Security Council that Member States are under obligation to prevent the financing of terrorism and the sheltering of the performers. Under paragraph 6 of this resolution, it was decided that Member States were obliged to report concrete measures taken to implement their obligations within 90 days to a committee set up for this purpose (Fidanci, 2006). Regardless of these obligations 
requiring State parties to assist each other in connection with criminal proceedings brought under a given convention or protocol, none of these conventions provides a clear definition of terrorism.

Despite the absence of a single universal definition of terrorism as mentioned above, it has to be acknowledged that there is an emerging consensus on certain elements regarding the definition of terrorism. Hence, it would suffice to note that three main elements seem to be required for the crime of international terrorism (Cassese, 2003). First, the acts must constitute a criminal offence under most national legal systems, such as murder, kidnapping, hostage-taking, bombing. In other words, the terrorist act must lie in conduct that is already criminalized under any national body of criminal law. Second, they must be aimed at spreading terror by means of violent action directed to a State, the public or particular groups of persons. It is undeniable fact that this element can be found in almost all definitions of terrorism used in national law (Walter et al., 2004). Hence, a number of international instruments and national laws provide that the objective pursued by terrorists may be either to spread terror among the population or to compel a government or an international organization to perform or abstain from performing an act. Third, they must be politically, religiously, or ideologically motivated. It cannot be denied that terrorism as an act of violence has been committed by people from all religious and political backgrounds. Hence, terrorism occurs when ideological motivation meets the operational capability.

Apart from that, scholars have been working on a definition of terrorism for decades now. Schmidt and Jongman in 1988 referenced 109 definitions of terrorism. The first thing that comes to mind is the important number of definitions that have been cataloged in 1988 . Levitt in 1986 commented: The search for a legal definition of terrorism in some ways resembles the quest for the Holy Grail: periodically, eager souls set out, full of purpose, energy and self-confidence, to succeed where so many others before have tried and failed. Levitt identified two different ways of defining terrorism: the "deductive method" and "the inductive method". On the one hand, deductive definitions of terrorism have three elements: (1) a substantive element (enumeration of deeds considered acts of terrorism), (2) the intent element (explicit mention that the act was intended) and (3) the jurisdictional element (towards whom the terrorist act is directed). On the other hand, the inductive method "relies upon a relatively precise description of the conduct constituting the substantive element and omits the political intent element that characterized the deductive approach". In other words, while inductive definitions aim at defining what a terrorist act is, deductive definitions try to answer the broader question of what terrorism is. The substantive element almost always refers to the use of violence and force. In their 1988 study, Schmidt and Jongman found that violence and force appear in $83.5 \%$ of the 109 definitions of terrorism, being by far the most recurrent theme.

In addition to the above, John Dugard considered in 1974 that an ideal definition of terrorism "should expressly state that motive is irrelevant in determining whether an act of terrorism has been committed". What mattered by then and throughout the 1970s was the nature of 
the act, and who the targets were. Most scholars have now shifted position on the issue, considering that a workable definition of terrorism should comprise the motive element. The absence of the motive element in international conventions is, as mentioned earlier, due to the need to reach consensus. States did not however discard deductive definitions of terrorism, as many of them use such definitions at the national level. The question of motive is one of the reasons for which the adoption of a universally recognized definition of terrorism has been stalled for years, despite the United Nations' continuous efforts to elaborate the Comprehensive Convention on International Terrorism since 1996.

In summary, the Security Council Resolution 1566, which was unanimously accepted by Council members in October 2004, may be a basis for hope that countries will overcome prior disputes, rise above their own interests, and reach an agreement in the near future regarding the international definition of terrorism. Resolution 1566, without serving as the definition itself, already establishes one basic principle on which an international definition can be built. It stipulates that terrorism is a crime against civilians, which in no circumstance can be justified by political, philosophical, ideological, racial, ethnic, religious, or other considerations.

\section{International Legal Instruments use in the Prevention of Terrorist Acts}

As mentioned earlier, terrorism has been on the international agenda since 1934, when the League of Nations took the first major step towards outlawing the scourge by discussing a draft convention for the prevention and punishment of terrorism. Although the Convention was eventually adopted in 1937, it never came into force due to the failure of the ratification process (Fidanci, 2006). Regardless of this state of affair, since 1963, the international community has elaborated 14 universal legal instruments and four amendments to prevent terrorist acts (United Nations Action to Counter Terrorism, http://www.un.org/en/terrorism/ instruments.shtml). Those instruments were developed under the auspices of the UN and its specialized agencies and the International Atomic Energy Agency (IAEA) and are open to participation by all Member States. In 2005, the international community also introduced substantive changes to three of these universal instruments to specifically account for the threat of terrorism; on 8 July of that year States adopted the Amendments to the Convention on the Physical Protection of Nuclear Material, and on 14 October they agreed to both the Protocol of 2005 to the Convention for the Suppression of Unlawful Acts against the Safety of Maritime Navigation and the Protocol of 2005 to the Protocol for the Suppression of Unlawful Acts against the Safety of Fixed Platforms Located on the Continental Shelf (United Nations Action to Counter Terrorism, http://www.un.org/en/terrorism/instruments. shtml).

Two more legal instruments were added in 2010: the 2010 Convention on the Suppression of Unlawful Acts Relating to International Civil Aviation and the 2010 Protocol Supplementary 
to the Convention for the Suppression of Unlawful Seizure of Aircraft. These treaties further criminalize the act of using civil aircraft as a weapon, and using dangerous materials to attack aircraft or other targets on the ground. The unlawful transport of biological, chemical and nuclear weapons and their related material becomes punishable under the treaties. Moreover, directors and organizers of attacks against aircraft and airports will have no safe haven. Making a threat against civil aviation may also trigger criminal liability.

From the foregoing discussion above, at present, there are 14 universal legal instruments or international conventions addressing terrorism and related activities, each covering a specific type of criminal activities (United Nations Action to Counter Terrorism, http://www. un.org/en/terrorism/instruments.shtml). The 14 universal legal instruments or international conventions are: 1963 Convention on Offences and Certain Other Acts Committed on Board Aircraft (Aircraft Convention); 1970 Convention for the Suppression of Unlawful Seizure of Aircraft (Unlawful Seizure Convention); 1971 Convention for the Suppression of Unlawful Act against the Safety of Civil Aviation (Civil Aviation Convention); 1973 Convention on the Prevention and Punishment of Crimes against Internationally Protected Persons (Diplomatic Agents Convention); 1979 International Convention against the Taking of Hostages (Hostages Convention); 1980 Convention on the Physical Protection of Nuclear Material (Nuclear Materials Convention); 1988 Protocol for the Suppression of Unlawful Acts of Violence at Airports, Serving International Civil Aviation, supplementary to the Convention for the Suppression of Unlawful Acts against the Safety of Civil Aviation (Airport Protocol); 1988 Protocol for the Suppression of Unlawful Acts against the Safety of Fixed Platforms Located on the Continental Shelf (Fixed Platform Protocol); 1991 Convention on the Making of Plastic Explosives for the Purpose of Detection (Plastic Explosives Convention); 1997 International Convention for the Suppression of Terrorist Bombings (Terrorist Bombing Convention); 1999 International Convention for the Suppression of the Financing of Terrorism (Terrorist Financing Convention); 2005 International Convention for the Suppression of Acts of Nuclear Terrorism (Nuclear Terrorism Convention); and 2010 Convention on the Suppression of Unlawful Acts Relating to International Civil Aviation (New Civil Aviation Convention).

It is obvious that all these Conventions require contracting States to introduce appropriate national laws in their own jurisdiction in order to punish the specific crimes mentioned by each Convention. Regrettably, implementation of these Conventions has not been easy and more importantly, no operational mechanism has been established to evaluate measures undertaken by the State parties. However, by way of resolution 1373 of 28 September 2001, it was decided by the UN Security Council that Member States are under obligation to prevent the financing of terrorism and the sheltering of the performers. Under paragraph 6 of this resolution, it was decided that Member States were obliged to report concrete measures taken to implement their obligations within 90 days to a committee set up for this purpose. But still there is a daunting task ahead due to the fact that even if State parties are under obligations to assist each other in connection with criminal proceedings brought 
under a given Convention or Protocol, none of these Conventions provide a clear definition of terrorism.

\section{Conclusion}

It is evident from the above discussions that making a single universally accepted definition of terrorism under international law is extremely difficult since there is always a possibility for the actions of a person or group being described as terrorism (criminal acts) by one side, while the same actions are deemed as an act of freedom (political acts) by the other side (Fidanci, 2006). For instance, the Palestine Liberation Organization (PLO) and other groups such as HAMAS (Islamic Resistance Movement) fighting against Israel in order to set up an independent state for their people are regarded as terrorist groups by Israel, but at the same time are considered as liberation movements by Muslims, and in particular the Arabs. As a matter of fact, legally defining terrorism is far from being an easy task. Even though everyone has a vague idea of what terrorism is, one has much trouble outlining what it is exactly.

There is no doubt that that a general definition of terrorism is necessary in order for the international community to fight against terrorism in a precise way. It is wholly admitted that although the term 'terrorism' might seem self-evident, in practice it is hard to agree upon a legal definition at the international level. From the foregoing discussions above, it is important to note that the international community has endorsed the inductive method by focusing merely on the substantive and jurisdictional element. This resulted in the adoption of sectoral conventions on terrorism. As a matter of fact, all of the 14 international conventions on terrorism listed by the UN connect terrorism with the use or threat of use of force and violence. It cannot be denied that there is a core definition of terrorism at international law that provides guidance to States enacting terrorism legislation, but that to have an effect, States must look to international law and accept its guidance (Young, 2006). As a concluding remark, the international definition of terrorism is destined to develop very slowly, and States need to tailor their legislation to specific national circumstances and respond to threats (Saul, 2006). The ease with which terrorists can cross borders means States cannot protect themselves simply by enacting and enforcing domestic legislation proscribing terrorism within their borders. Rather, every State must have legislation denying terrorists safe havens and safe places of operation. An established minimum international law definition of terrorism that informs States' domestic criminal law is required to ensure a baseline of consistency and to facilitate international cooperation. The core definition identified in this paper provides that minimum as well as a yardstick against which to measure States' legislation. The existence of a definition of terrorism is important. It shapes States' understanding of the problem, delimits their responses to it, and helps to distinguish lawful from unlawful responses (Young, 2006). The perceived absence of an accepted international law definition is said by some largely to explain the inadequacy of international law's ability to combat terrorism. 


\section{References}

Adam, R. (2005). The war on terror in historical perspective. Survival: Global Politics and Strategy, 47(2), 101-130. Retrieved from http://www.iiss.org/en/publications/ survival/sections/2005-9d59/survival-global-politics-and-strategy-summer-20053623/05-roberts-fb0e

Begorre-Bret, C. (1988). The definition of terrorism and the challenge of relativism. Cardozo Law Review, 27(5), 1987-2004.

Carlton, D., \& Schaerf, C. (1975). International terrorism and world security. London: Croom Helm Press.

Cassese, A. (2003). International criminal law. Oxford: Oxford University Press.

Dugard, J. (1974). International terrorism: Problems of definition. International Affairs, $50(1), 67-81$.

Dumitriu, E. (2005). The EUs definition of terrorism: The council framework decision on combating terrorism. German Law Journal, 5(5), 585-602.

Fidanci, S. (2006). Definition of terrorism in international law. The Journal of Turkish Weekly. Retrieved from http://www.turkishweekly.net/article/103/definition-ofterrorism-in-international-law.html

Foerster, V. H., Mora, M. P., \& Amiot, W. L. (1960, November). Doomsday: Friday, 13 November, AD 2026. Science New Series, 132(3436), 1291-1295. Retrieved from http://tuvalu.santafe.edu/ bn/reading_group/vonFoerster_et_al.pdf

Ganor, B. (2002). Defining terrorism: Is one man's terrorist another man's freedom fighter? Police Practice and Research, 3(4), 287-304.

Golder, B., \& Williams, G. (2004). What is terrorism? Problems of legal definition. University of New South Wales Law Journal, 27(2), 270-295.

Halberstam, M. (2003). The evolution of the United Nations position on terrorism: From exempting national liberation movements to criminalizing terrorism wherever and by whomever committed. Columbia Journal of Transnational Law, 41, 573-582.

Hassan, O. A. (2011). International terrorism and the legal and political manifestations. Egypt: Aldar Legal Books Press. 
Hickman, J. D. (2011). Terrorism as a violation of the law of nations: Finally overcoming the definitional problem. Wisconsin International Law Journal, 29(3), 447-483.

Hoffman, B. (1998). Inside terrorism 28. Columbia: Columbia University Press.

Juergensmeyer, M. (2003). Terror in the mind of God: The global rise of religious violence. London: University of California Press.

Levitt, G. (1986). Is terrorism worth defining? Ohio Northern University Law Review, 13, 97-115.

Marston, G. (2002). Early attempts to suppress terrorism: The terrorism and international criminal court conventions of 1937. British Yearbook of International Law, 73(10), 293-313.

Rostow, N. (2002). Before and after: The changed UN response to terrorism since September 11th. Cornell International Law Journal, 35, 475-489.

Saul, B. (2005). Attempts to define terrorism in international law. Netherlands International Law Review, 52(1), 57-83.

Saul, B. (2006). Defining terrorism in international law. Oxford: Oxford University Press.

Schmid, A. (2004a). Terrorism: The definitional problem. Case Western Reserve Journal of International Law, 36(375), 375-419.

Schmid, A. (2004b). Framework for conceptualizing terrorism. Terrorism and Political Violence, 16(2), 197-221.

Schmid, A. (Ed.). (2011). Handbook of terrorism research. London: Routledge.

Schmid, A. (2012). The revised academic consensus definition of terrorism. Perspectives on Terrorism, 6(2), 158-159. Retrieved from http://www.terrorismanalysts.com/pt/ articles/issues/PTv6i2.pdf

Schmid, A., \& Jongman, A. (1988). Political terrorism. A new guide to actors, authors, concepts, databases, theories and literature. Amsterdam: North-Holland Publishing Company.

Sunga, L. (1997). The emerging system of international criminal law: Developments in codification and implementation. The Hague: Kluwer International Law. 
Walter, C., Voneky, S., Roben, V., \& Schorkopf, F. (Eds.). (2004). Terrorism as a challenge for national and international law: Security versus liberty. Berlin: Springer.

Young, R. (2006). Defining terrorism: The evolution of terrorism as a legal concept in international law and its influence on definitions in domestic legislation. Boston College International and Comparative Law Review, 29, 23-1050. 